\title{
STRATEGI PEMBELAJARAN TRANSFORMATIF
}

\author{
Oleh Dr. Purim Marbun, M. Th
}

\begin{abstract}
ABSTRAK
Tulisan ini memberikan paparan tentang strategi pembelajaran transformative, sebuah pendekatan dan metode yang tidak hanya mengimplementasikan kemampuan guru dalam mengajar serta memperhatikan gaya belajar murid, melainkan mengedepankan faktor kuasa Roh Kudus dalam menyelesaikan tugas mengajar. Pembelajaran transformative dilakukan di kelas bertujuan membawa perubahan karakter peserta didik, guru atau dosen bukan saja bertindak sebagai pribadi yang mentransfer knowledge tetapi juga figur yang menginspirasi perubahan. Strategi ini dapat dilakukan dengan efektif bila interaksi guru atau dosen dengan peserta didik dalam situasi yang kondusif dalam pimpinan Roh Kudus..
\end{abstract}

Kata kunci: Strategi pembelajaran, Roh Kudus, Transformatif

PENDAHULUAN

Salah satu aspek penting dalam proses pembelajaran ialah masalah strategi pembelajaran. Pada prinsipnya strategi pembelajaran merupakan bagian sentral dalam meningkatkan kualitas dan hasil belajar. Tanpa strategi yang baik, tidak mungkin didapatkan hasil belajar yang optimal. Istilah yang dekat dengan strategi pembelajaran yakni pendekatan, metode, teknik, model dan strategi.

Pendekatan dapat diartikan sebagai titik tolak atau sudut pandang kita terhadap proses pembelajaran. Pendekatan yang berpusat pada guru menunjukkan strategi pembelajaran langsung (direct instruction), pembelajaran deduktif atau pembelajaran ekspositori, sedangkan, pendekatan pembelajaran yang berpusat pada siswa menurunkan strategi pembelajaran discovery dan inkuiri serta strategi pembelajaran induktif. Metode pada umum-nya merupakan jabaran dari pendekatan. Satu pendekatan dapat dijabarkan ke dalam berbagai metode dalam kelas pembelajaran.

Metode adalah prosedur pembelajaran yang difokuskan ke pencapaian tujuan. Teknik dan taktik mengajar merupakan penjabaran dari metode pembelajaran. Teknik adalah cara yang dilakukan seseorang dalam rangka mengimplementasikan suatu metode. Misalnya, cara yang bagaimana yang harus dilakukan agar metode ceramah yang dilakukan berjalan efektif dan efisien? Dengan demikian sebelum seorang melakukan proses ceramah sebaiknya memperhatikan kondisi dan situasi.

Model pembelajaran adalah bentuk pembelajaran yang tergambar dari awal sampai akhir yang disajikan secara khas oleh guru di kelas. Dalam model pembelajaran terdapat strategi pencapaian kompetensi siswa dengan pendekatan, metode, dan teknik pembelajaran. Strategi pembelajaran dapat diartikan sebagai perencanaan yang berisi tentang rangkaian kegiatan yang didesain untuk mencapai tujuan pendidikan tertentu.

Selanjutnya strategi pembelajaran adalah suatu kegiatan pembelajaran yang harus dikerjakan guru dan siswa agar tujuan pembelajaran dapat dicapai secara efektif dan efisien. Istilah strategi sering digunakan dalam banyak konteks dengan makna yang selalu sama. Dalam konteks pengajaran strategi bisa diartikan sebagai suatu pola umum tindakan guru-peserta didik dalam manifestasi aktivitas pengajaran.

\section{ASPEK-ASPEK PEMBANGUN STRA- TEGI PEMBELAJARAN}

\section{Tujuan Pembelajaran}

Tujuan pembelajaran adalah hal yang sangat esensial dalam proses pendidikan di sebuah institusi sekolah. Tanpa tujuan pembelajaran maka ke- 
seluruhan proses yang dikerjakan dalam pembelajaran akan menjadi sia-sia. Sebelum membahas lebih lanjut tentang tujuan pembelajaran lebih dahulu dipaparkan konsep tentang pembelajaran.

Dalam buku Profesionalisme Guru dalam Pembelajaran, Zainal Aqib menyebutkan pembelajaran adalah suatu kombinasi tersusun meliputi unsur manusiawi, materil, fasilitas, perlengkapan dan prosedur yang saling mempengaruhi untuk mencapai tujuan pembelajaran. ${ }^{1}$ Unsur manusiawi yang dimaksud dalam penjelasan di atas adalah guru sebagai pengajar dan peserta didik (mahasiswa) sebagai pribadi yang belajar. Lebih lanjut dapat disebutkan bahwa pembelajaran merujuk kepada adanya proses yang menghubungkan semua unsur-unsur di atas, sehingga terjadi proses belajar (pembelajaran).

Menurut Muhtar dan Martinis Yamin, pembelajaran merujuk kepada adanya input, proses dan output. Dalam bukunya yang berjudul Metode Pembelajaran yang berhasil disebutkan bahwa pembelajaran merujuk kepada tiga unsur yakni input, proses dan output. Pada sisi input pembelajaran harus memiliki konsep yang jelas, materi yang jelas, pembelajar yang jelas dan perencanaan sesuai kurikulum. Pada sisi proses pembelajaran harus memiliki sumber-sumber yang sesuai, model yang pas bagi tiap mata kuliah dan kesesuaian antara audiens dengan suasana belajar, sedangkan dari sisi output pembelajaran harus mem-berikan kontribusi bagi siswa yakni proses pendewasaan, pengayaan keterampilan dan ilmu pengetahuan. ${ }^{2}$

Senada dengan penjelasan di atas, Ad. Rooidjakkers menamakan pembelajaran dengan sebutan proses belajar.

${ }^{1}$ Zainal Aqib, Profesionalisme Guru Dalam Pembelajaran, (Surabaya: Insan Cendikia, 2002), 41.

${ }^{2}$ Mukhtar \& Martinis Yamin, Metode Pembelajaran Yang Berhasil, (Jakarta: Sasama Mitra Sukses, 2002), 1
Menurutnya proses belajar adalah situasi dimana mahasiswa atau pelajar berada dalam sebuah lingkungan interaksi dengan guru yang di dalamnya ada kegiatan atau proses transfer ilmu. ${ }^{3}$ Menurutnya pembelajaran itu adalah proses belajar dari tidak tahu menjadi mengerti. Untuk dapat mengerti maka ada hal-hal yang terkait dengan proses itu mahasiswa atau peserta didik harus memiliki motivasi, perhatian terhadap pelajaran yang diberikan guru, belajar mengingat dan latihan-latihan. ${ }^{4}$

Pembelajaran atau proses belajar masih menurut Ad. Rooidjakkers memiliki dua proses yakni proses intern dan ekstern. Proses intern meliputi apa yang dikerjakan oleh mahasiswa dalam belajar, pada garapan ini mahasiswa harus memiliki lima hal yakni: motivasi, perhatian pada pelajaran atau kuliah, menerima dan mengingat, reproduksi yakni mahasiswa bukan saja menerima informasi me-lainkan belajar menemukan makna yang dapat diaplikasikan tersendiri dan generasilasi yakni mahasiswa menempat-kan pengetahuan yang didapat untuk kebermaknaan yang lebih luas. ${ }^{5}$ Sedangkan proses ekstern meliput tugas guru atau pengajar melakukan proses transfer ilmu, di mana seorang pengajar perlu membangun hubungan dengan mahasiswa, merangsang minat mahasiswa, penjelasan yang relevan, mengarahkan mahasiswa untuk pengetahuan yang telah ada. ${ }^{6}$

Dari paparan di atas dapat disimpulkan bahwa strategi pembelajaran adalah proses interaksi antara guru dan mahasiswa yang di dalamnya terdapat relasi edukatif bertujuan mengembangkan pengetahuan dan pemahaman mahasiswa. Dengan demikian pembelajaran dapat disebutkan sebagai kegiatan interaksi edukatif dalam konteks waktu tertentu di

${ }^{3}$ Ad. Rooijakkers, Mengajar Dengan Sukses: Petunjuk untuk Merencankan dan Menyampaikan Pengajaran, (Jakarta: Grasindo dan YKPTK, 1993), 15.

${ }^{4}$ Ad. Rooidjakker, 14.

${ }^{5}$ Ad. Rooidjakkers, 21.

${ }^{6}$ Ad. Rooidjakkers, 27 
mana guru sebagai pengajar dan mahasiswa sebagai pelajaran memiliki tujuan yang telah direncanakan.

Salah satu bagian yang perlu diperhatikan dalam strategi pembelajaran adalah tujuan pembelajaran. Tujuan pembelajaran (leraning objectives) adalah istilah yang menggabungkan (compounding) dua kata yaitu learning yang berarti belajar atau pembelajaran dan kata objectives yang berarti tujuan. Secara harfiah istilah itu berarti tujuan belajar. ${ }^{7}$ Senada dengan penjelasan di atas Cranton seperti dikutip oleh Zaini menjelaskan bahwa tujuan pembelajaran adalah pernyataan-pernyataan tentang pengetahuan dan kemampuan yang diharapkan dari peserta setelah selesai pembelajaran. ${ }^{8}$

Menurut Soekartawi perlunya tujuan pembelajaran untuk mengukur sasaran yang akan dicapai, karena itu tujuan diklasifikasikan dalam dua jenis antara lain tujuan umum dan khusus. Tujuan umum menurutnya sering disebut dengan goals dari bahan ajar yang disampaikan sedangkan tujuan khusus disebut dengan objectives. ${ }^{9}$ Dalam aplikasi praktis tujuan umum (goals) dan tujuan khusus (objectives) biasanya terdapat pada silabus. Dahulu keduanya dikenal dengan tujuan instruksional umum dan tujuan instruksional khusus. Biasanya pada tataran praktis tujuan umum lebih merangkum halhal yang konseptual dan tujuan khusus lebih operasional. Soekartawi menambahkan bahwa tujuan umum biasanya hanya satu dalam tiap silabus, sedangkan tujuan khusus lebih dari satu, dan sifatnya operasional. ${ }^{10}$

Fungsi dari tujuan pembelajaran adalah terdiri tiga hal, pertama mengorganisasikan bahan ajar. Dalam hal ini kegiatan dimulai dari memilih dan menetapkan bahan ajar yang sesuai dan

\footnotetext{
${ }^{7}$ Hisyam Zaini, Desain Pembelajaran di Perguruan Tinggi, Jawa Timur: CTSD, 2006, 56

${ }^{8}$ Hisyam Zaini, 56.

${ }^{9}$ Soekartawi, Meningkatkan Efektivitas Mengajar, (Jakarta: Dunia Pustaka Jaya, 1995), 41.

${ }^{10}$ Soekartawi, 41.
}

mampu mencapai tujuan instruksional mata kuliah. Kedua, mengindentifikasi karakteristik mahasiswa, kondisi dan lingkungan pengajaran untuk dapat memilih dan menetapkan kegiatan pembelajaran, dan yang ketiga menentukan kriteria pengukuran ketercapaian pembelajaran. ${ }^{11}$ Tujuan pembelajaran mempengaruhi organisasi pembelajaran yang meliputi urutan dari pokok bahasan yang akan disajikan. Pokok bahasan dan sub pokok bahasan harus dijadikan untuk menetapkan sasaran belajar (learning outcomes) yang terukur dan bisa diamati.

Tujuan pembelajaran atau yang lazim disebut juga dengan tujuan instruksional mengandung unsur-unsur yang dapat memberikan petunjuk kepada penyusuan alat test. Oleh karena itu biasanya memiliki aspek-aspek yang sering dinyatakan dengan istilah $\mathrm{ABCD}$ yaitu: $\mathrm{A}=$ Audience (siswa, mahasiswa); $\mathrm{B}=$ Behaviour (tingkah laku); Condition (kondisi); dan D = Degree (tingkatan). Dan dalam tujuan pembelajaran minimal mengandung unsur audience dan behaviour. $^{12}$

Istilah learning objectives (LO) atau learn-ing outcomes pada dasarnya menunjukkan tujuan belajar secara khusus. Istilah yang populer di Indonesia adalah tujuan instruksional yang dibagi menjadi dua yakni tujuan instruksional umum dan tujuan instruksional khusus. Tujuan instruksional umum adalah pernyataan yang menggambarkan kemampuan umum yang seharusnya dicapai mahasiswa setelah menyelesaikan mata kuliah dan tujuan instruksional khusus adalah tujuan yang menggambarkan hasil belajar yang harus dicapai oleh mahasiswa setelah tatap muka dengan satu pokok bahasan atau topik tentu. Kedua tujuan ini arus dimunculkan dan

\footnotetext{
${ }^{11}$ Soekartawi, dkk., Meningkatkan Rancangan Instruksional (Instructonal Design) Untuk Memperbaiki Kualitas Mengajar, (Jakarta: Raja Grafindo Persada, 1995), 16.

${ }^{12}$ Soekartawi dkk., 17
} 
diformulasikan dalam satuan acara perkuliahan (SAP). ${ }^{13}$

Sejalan dengan penjelasan di atas Jerold E. Kemp dkk, dalam bukunya Designing Effective Instruction, menyebutkan bahwa tujuan instruksional (instructional objectives) merupakan dasar dan panduan merancang dan mengembangkan pembelajaran. ${ }^{14}$ Selain itu menurut Kemp pentingnya tujuan instruksional tersebut adalah merumuskan aktivitas yang akan dilakukan.

Kemp menyebutkan: " The instructional objective specify exactly what the learner must muster. The objectives provide a map for designing the instruc-tion and for developing the means to assess learner performance. We use the objectives as one of our fisrt quality checks to make sure that the instruction (including the learning activities) we develop is focused on solving the performance problem. ${ }^{15}$

Tujuan instruksional khusus biasa juga disebut dengan tujuan pembelajaran khusus (TPK), sifatnya sama dengan learning objectives hanya perbedaannya hanya merujuk kepada satu kali tatap muka saja. Kepentingan dari tujuan pembelajaran khusus menurut Mager dalam bukunya yang berjudul Preparing Instructional Objectives seperti dikutip Hisyam Zaini adalah sebagai berikut: (a) dasar bagi perencanaan mata kuliah; (b) memberikan kesempatan untuk meng-evaluasi hasil; (c) memberikan arah yang jelas bagi mahasiswa. ${ }^{16}$ Tujuan pem-belajaran seharusnya tergambar dari kuri-kulum atau rencana pembelajaran yang akan disajikan. Oleh karena esensi tujuan pembelajaran sangat penting dan prinsipil, maka dalam desain integrated curriculum, seharusnya bagian ini menjadi patokan dasar yang tidak boleh diabaikan.

2. Materi Pembelajaran

${ }^{13}$ Hisyam Zaini, 57.

${ }^{14}$ Jerold E. Kemp dkk, Designing

Effective Instruction, (Denver: John Wiley \& Son Inc, 2007), 16.
Materi pembelajaran sering disebut bahan ajar atau bahan belajar. Bahan belajar dapat berupa benda atau isi pendidikan. Isi pendidikan tersebut berupa pengetahuan, nilai, sikap dan metode. ${ }^{17}$ Yang paling bertanggung jawab untuk menentukan materi pembelajaran ini adalah guru atau dosen. Berdasarkan pada kurikulum yang dimiliki, dosen harus mampu mengolah bahan ajar yang akan disampaikan dalam kelas pembelajaran.

Salah satu tugas guru atau dosen yang sangat menyita waktu, tenaga dan pemikiran adalah merencanakan materi pembelajaran. Mengapa demikian? Karena dari sudut pandang guru atau dosen, mengajar adalah menyampaikan sejumlah materi pembelajaran (content) yang dikomunikasikan kepada peserta didik atau mahasiswa. Materi pembelajaran lazim juga disebut dengan bahan pengajaran, jika guru atau dosen mengajar tentu ia harus memiliki bahan pengajaran. Dari segi mahasiswa yang belajar materi pengajaran yang disampaikan oleh dosen disebut dengan bahan pelajaran.

Dalam merumuskan bahan pengajaran seorang dosen harus memperhatikan content curriculum yang terdapat pada Garis-Garis Besar Program Pengajaran (GBPP). Untuk merumuskan bahan pengajaran (materi), B.S. Sidjabat dalam bukunya Mengajar Secara Profesional memberikan beberapa cara dosen mempersiapkan bahan peng-ajaran yakni: pertama, dosen menetapkan sendiri bahan yang akan diajar sesuai dengan kehendaknya, dengan mempertimbangkan keahliannya dalam mata kuliah tertentu; kedua, dosen menetapkan dan mengembangkan bahan pengajaran setelah berkonsultasi dan berdiskusi dengan peserta didiknya; ketiga, dosen menetapkan bahan pembelajaran bersama-sama dengan peserta didik; keempat, dosen menetapkan dan mengembangkan bahan berdasar-kan

\footnotetext{
15 Jerodl E. Kemp dkk, 16.

${ }^{16}$ Hisyam Zaini, 60

${ }^{17}$ Dimiyati \& Mudjiono, 33
} 
kurikulum baku seperti Garis-Garis Besar Program Pengajaran (GBPP) yang ditetapkan oleh pihak yang berwenang. ${ }^{18}$

Cara umum dilakukan oleh dosen dalam menyusun bahan pengajaran atau materi pembelajaran adalah dengan melihat tujuan pembelajaran, baik tujuan umum maupun tujuan khusus. Dalam Satuan Acara Perkuliahan yang dibuat oleh dosen terdapat tujuan pembelajaran khusus, berdasarkan tujuan inilah disusun materi pembelajaran. Soekartawi dalam buku Meningkatkan Rancangan Instruksio-nal memberikan penjelasan bahwa skema proses pembelajaran selalu mengikuti matriks Satuan Acara Perkuliahan, yang didalamnya memperlihatkan hubungan tujuan pembelajaran khusus dengan materi yang akan diajarkan. ${ }^{19}$

Dalam bentuk yang lebih utuh materi pembelajaran bisa disebut dengan diktat mengajar. Untuk menyusunnya dosen perlu merancang garis besar perkuliahan berdasarkan rancangan instruksional dengan langka-langkah mengikuti alur dari tujuan yang akan dicapai. Berdasarkan tujuan pembelajaran khusus seorang dosen mengetahui bagaimana perkuliahan ditempuh dan materi diurutkan dengan susunan yang progresif.

Dalam merencanakan bahan pengajaran dan silabus, guru atau dosen dituntut memiliki kemampuan mengembangkan pemahaman yang komprehensif tentang tujuan umum dan khusus dari mata kuliah yang disajikan. Berdasarkan tujuan yang ada dosen mampu memperkirakan bagaimana cara mengorganisasikan bahan ajar. Lebih lanjut menurut B.S. Sidjabat dalam merancang materi pembelajaran guru harus mempertimbangkan faktor peserta didik atau mahasiswa dalam hal kematangan berpikir, perkembangan emosi dan kemampuan akademis. ${ }^{20}$ Selain faktor

\footnotetext{
${ }^{18}$ B.S. Sidjabat, Mengajar Secara

Profesional, (Bandung: Kalam Hdup, 2011),207.

${ }^{19}$ Soekartawi dkk., 48.
}

mahasiswa yang akan belajar, dosen juga wajib memperhatikan faktor waktu yang tersedia dalam menyajikan materi pembelajaran. Dosen harus matang dalam mengkalkulasi banyak sedikitnya materi yang disajikan dengan waktu yang tersedia.

Faktor lain yang mempengaruhi perumusan dan pengembangan materi pembelajaran adalah manfaat dan relevansinya bagi kehidupan mahasiswa baik untuk masa kini pun masa yang akan datang. Sijabat menjelaskan bahwa pertimbangan manfaat harusnya mendorong para dosen untuk mempertimbangkan tujuan pengajaran jangka pendek dan jangka panjang. Menurutnya dosen atau pengajar harus bisa "membaca" manfaat pembelajaran dengan memperhitungkan relevansi materi pembelajaran, bukan saja hanya dalam konteks pemahaman, konsep berpikir, tetapi juga hal yang menyentuh spiritual. $^{21}$

Untuk tujuan kemanfaatan bahan pengajaran, Soekartawi memberikan masukan bahwa setiap dosen harus menetapkan buku-buku wajib setiap mata kuliah. Jika dosen harus membuat diktat maka hal itu harus berisikan materi pembelajaran yang up to date (materi tidak kuno). Oleh karena pendididikan dan pembelajaran sifatnya progresif maka dosen dalam merancang diktat atau hand out, harus relevan dengan perkembangan zaman. $^{22}$

Salah satu hambatan bagi dosen dalam mengembangkan materi pembelajaran adalah ketidakmampuan membuat relevansi pengajaran dengan kehidupan masa kini. Hal ini bisa disebabkan oleh karena kurangnya kreativitas, puas dengan bahan atau materi pembelajarn yang telah tersedia, atau bisa juga oleh karena "malas" mengupdate materi yang hendak disampaikan. Pertimbangan yang harus dilakukan oleh dosen dalam

\footnotetext{
${ }^{20}$ B.S. Sidjabat, 209.

${ }^{21}$ B.S Sidjabat, 209.

${ }^{22}$ Soekartawi dkk., 48.
} 
mengembangkan bahan ajar, harus komprehensif dan luas. Merujuk kepada hal ini maka berbagai faktor harus diperhatikan.

\section{Gambar 1. Faktor Pertimbangan Menyusun Bahan Pengajaran}

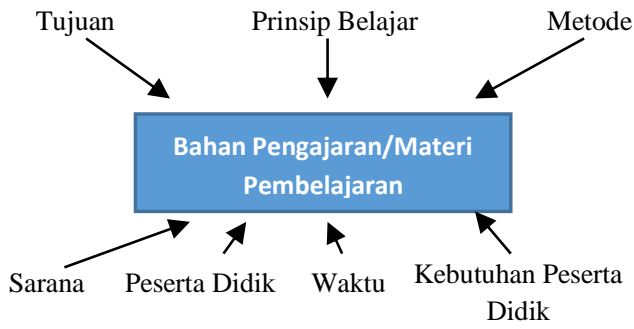

Dari uraian di atas dapat disimpulkan bahwa materi pembelajaran merupakan unit penting dan esensial yang harus diperhatikan oleh guru atau institusi pendidikan dalam merancang kurikulum. Apalagi dalam kaitan merancang integrated curriculum maka perhatian terhadap bahan pengajaran mutlak diperlukan. Materi pengajaran tidak bisa dipisahkan dari rancangan kurikulum.

\section{STRATEGI PEMBELAJARAN TRANSFORMATIF}

\section{Istilah pembelajaran (instruction)} dapat dimaknai sebagai upaya membelajarkan seseorang atau sekelompok orang (mahasiswa) melalui berbagai upaya dan strategi, metode dan pendekatan untuk mencapai tujuan belajar. Dalam tataran praktis strategi pembelajaran merujuk kepada suatu konsep dua dimensi kegiatan (belajar dan meng-ajar) yang harus direncanakan aktuali-sasinya, serta diarahkan pada pencapaian tujuan. ${ }^{23}$

$$
\text { Pada dasarnya pembelajaran }
$$
membutuhkan strategi dan metode pem-

${ }^{23}$ Abdul Majid, Strategi Pembelajaran,

(Bandung: Rosda Karya, 2013), 15.

${ }^{24}$ Abdul Majid, 7

${ }^{25}$ Ridwan Abudllah Sani, Inovasi

Pembelajaran, (Jakarta: Bumi Aksara, 2013), 89. belajaran. Strategi pembelajaran adalah pendekatan menyeluruh dalam suatu sistem pembelajaran yang berupa pedoman umum dan kerangka kegiatan untuk mencapai tujuan umum pembelajaran yang dijabarkan dari pandangan falsafah atau tori belajar. Lebih lanjut menurut Kemp, seperti dikutip oleh Abdul Majid menjelaskan bahwa strategi pembelajaran adalah suatu kegiatan pembelajaran yang harus dikerjakan guru atau dosen dan peserta didik agar tujuan dapat dicapai secara efisien dan efektif. ${ }^{24}$

Strategi pembelajaran merupakan rencana tindakan termasuk penggunaan metode dan pemanfaatan berbagai sumber daya dalam pembelajaran. Lebih lanjut disebutkan bahwa strategi pembelajaran menentukan pendekatan yang dipilih dosen untuk mencapai tujuan pem-belajaran, yang secara rinci meliputi pendekatan, teknik pembelajaran dan metode pembelajaran. ${ }^{25}$ Dari uraian di atas strategi dan metode pembelajaran dapat dilihat menjadi satu kesatuan. Gerlach dan Ely seperti dikutip oleh Abdul Majid menjelaskan bahwa strategi pembelajaran merupakan cara-cara yang dipilih untuk menyampaikan materi pembelajaran dalam lingkuan pembelajaran tertentu. ${ }^{26}$ Sedang-kan Wina Sanjaya mengatakan bahwa strategi berkaitan seluruh kom-ponen materi pembelajaran dan prosedur tahapan kegiatan belajar yang dilakukan oleh dosen, yang terkait dengan pengaturan materi, paket program belajar, dan metode menyampaikan kepada peserta didik. $^{27}$

Dari penjelasan-penjelasan di atas maka dapat disimpulkan bahwa strategi pembelajaran merupakan rencana tindakan (kegiatan pembelajaran) yang di dalamnya termasuk penggunaan metode belajar mengajar dan pemanfaatan berbagai sumber daya. Oleh karena itu strategi dan metode pembelajaran dapat digolongkan

\footnotetext{
${ }^{26}$ Abdul Majid, 7.

${ }^{27}$ Wina Sanjaya, Perencanaan dan Desain Sistem Pembelajaran, (Jakarta: Prenada Media Group, 2008), 25.
} 
kepada tiga bagian. Pertama sebagai ilmu, strategi pembelajaran digunakan oleh pendidik atau dosen dengan menerapkan fungsi-fungsi dan prinsip ilmiah dari berbagai teori psikologi, sosiologi dan antropologi. Kedua, sebagai seni strategi pembelajaran dimaknai bahwa pendidik melakukan upaya peniruan, modifikasi, penyempurnaan dan pengembangan alternatif model pembelajaran yang ada untuk penumbuhan kegiatan belajar mahasiswa yang disesuaikan dengan kebutuhan, potensi dan situasi lingkungan. Ketiga, dari segi keterampilan strategi pem-belajaran, pendidik melaksanakan pem-belajaran dengan menggunakan metode, teknik, dan media pembelajaran yang telah dikuasai secara profesional, sehingga kegiatan terlaksana secara tepat sesuai rencana yang telah ditetapkan. ${ }^{28}$

Dalan Undang-Undang yakni PP No.19 tahun 2005 dijelaskan bahwa proses pembelajaran harus diselenggarakan secara interaktif, inspiratif, menyenangkan, memberikan ruang gerak yang cukup bagi pengembangan prakarsa, kreativitas sesuai bakat, minat dan perkembangan fisik serta psikologi peserta didik. ${ }^{29}$ Upaya pengembangan pembelajaran yang efektif menuntut pemilihan metode yang akurat. Pemilihan metode tersebut akan mempengaruhi proses kreatif dalam pembelajaran. Marlene D. LeFerer dalam buku Creative Teaching Methods menjelaskan bahwa: " The potential a creative teacher is like a dare- a dare to think new thought and try new things, not because newness in itself is something to be coveted, but becauce he or she is following the Master Teacher who use interactive methods to prepare His small band of student to change history" 30 Dari teks ini dapat diterjemahkan secara sederhana kreatifitas dalam mengajar sangat dipengaruhi keinginan kemampuan guru untuk men-coba sesuatu yang baru,

${ }^{28}$ Abdul Majid, 9

${ }^{29}$ PP No 19. Tahun 2005 dan mengikuti pola pengajaran yang sering digunakan ole Tuhan Yesus.

Salah satu metode yang digunakan ole Yesus yang sangat kreatif adalah perumpamaan dan cerita. Marlen De LeFerer menegaskan: " Jesus use lecture and storry telling. People listened as $\mathrm{He}$ told simple stories filles with eternal truth. He uses object lessons. The fig tree withered and His diciples understood." 31 Keberhasilan kreativitas Yesus dalam mengajar bukan sekedar pada pemilihan metode melainkan pada pendekatan dan kemahirannya dalam menyampaikan materi dengan metode yang simpel, namun berdampak pada penyampaian kebenaranNya. Lebih lanjut Yesus mendorong setiap murid-muridnya memahami dan mengerti apa yang disampaikan.

Strategi pembelajaran transformatif adalah metode dan pendekatan yang dilakukan oleh guru atau dosen menyampaikan materi dengan cara yang inspiratif, edukatif dan juga membawa perubahan. Seperti dijelaskan di atas oleh Le Ferer, Yesus meng-gunakan strategi pembelajaran yang transformatif. Dia mampu menggunakan berbagai metode yang sanggup menyentuh pendengarnya, bahkan mendorong mereka untuk melakukan tindakan-tindakan perbuatan. Semua metode yang digunakan Yesus jelas mempengaruhi para pendengarnya bahkan cenderung menghasilkan perubahan.

Dalam Injil Matius 7:28-29, kesaksian Alkitab menjelaskan bahwa ketika Yesus mengajar dan mengakhiri perkataanNya, takjublah orang banyak terhadap pengajaranNya, karena ia mengajar sebagai orang yang berkuasa. Berdasar pada teks tersebut, salaha satu faktor yang memberi sumbangan besar bagi strategi pengarajan transformatif ialah kuasa yang dimiliki oleh Yesus, sehingga pengajarannya bukan retortika melainkan

\footnotetext{
${ }^{30}$ Marlen D. LeFerer, Creative Teaching Methods:Be An Effective Christian Teacher, (Elgin: David C.Cook Publishing Co, 1988), 12.

${ }^{31}$ Marlene D. Le Ferer, 12.
} 
kuasa yang bekerja kepada semua pendengarnya.

Berbagai strategi pembelajatan transformatif yang dapat dilakukan oleh guru dan dosen dalam kelas pembelajaran antara lain:

(1) Strategi Pembelajaran Interaktif (interactive instruction)

Strategi pembelajaran interaktif merujuk kepada bentuk diskusi dan saling berbagi di antara mahasiswa. Seaman dan Fellenz mengemukakan bahwa diskusi dan saling berbagi akan memberikan kesempatan kepada mahasiswa untuk memberikan reaksi terhadap gagasan, pengalaman, pandangan dan pengetahuan dosen atau kelompok serta mencoba mencari alternatif berpikir. Strategi pembelajaran interaktif dikembangan dalam rentang pengelompokan dan metode interaktif. Didalamnya terdapat bentukbentuk diskusi kelas, diskusi kelompok kecil atau pengerjaan tugas berkelompok dan kerja sama mahasiswa secara berpasangan. Dalam Perjanjian Baru, ditemukan model ini dilakukan oleh Yesus, seringkali Yesus berdialog, diskusi dengan murid-muridNya. Tujuan utamanya ialah mendorong dan memotivasi pendengarnya mengalami perubahan.

(2) Strategi Pembelajaran melalui Pengalaman (experiential learning)

Strategi belajar melalui pengalaman menggunakan bentuk sekuens induktif, berpusat pada mahasiswa dan berorientasi pada aktivitas. Penekanan daam strategi belajar melalui pengalaman adalah proses belajar bukan hasil belajar. Dosen dapat menggunakan strategi ini baik di dalam kelas maupun di luar kelas. Experiential learning dapat menghasilkan perubahan karena dalam bagian ini

(3) Strategi Pembelajaran Mandiri

Belajar mandiri merupakan strategi pembelajaran yang bertujuan untuk membangun inisiatif individu, kemandirian dan peningkatan diri. Fokusnya adalah perencanaan belajar mandiri oleh peserta didik. Kelebihan pembelajaran ini menjadikan peserta didik bertanggung jawab dan mandiri. ${ }^{32}$ Dalam mengimplementasikan pembelajaran mandiri setiap peserta didik sangat bergantung kepada tuntunan dan pimpinan Roh Kudus, secara individual mereka dapat melaksanakan pembelajaran dengan pertolongan hikmat dan kebijaksanaan yang diberi Roh kepada mereka

Strategi pembelajaran transformatif adalah pendekatan, metode dan strategi mengajad dan belajar bukan hanya sekedar transfer knowledge, melainkan relasi antara guru dan murid yang meng-hasikan nilainilai positif dan berdampak bagi pengembangan ilmu dan perubahan karakter. Dalam konteks pembelajaran Pendidikan Agama Kristen, pola yang dilakukan tidak saja menekankan disiplin ilmu dan metode mengajar melainkan menggantungkan diri kepada kuasa Roh Kudus. Roh Kudus menjadi inspirasi dan sumber kemampuan utama dalam melakukan tugas-tugas mengajar.

\section{KESIMPULAN}

Pengembangan strategi pembelajaran merupakan tugas guru atau dosen yang merujuk kepada kompetensi profesionalisme. Para guru atau dosen harus piawai dalam merancang strategi pembelajaran yang tepat dengan mempertimbangkan segala aspek, bukan hanya menyangkut aspek kecakapan guru dalam mengajar, namun juga mempertimbangkan aspek kesiapan anak didik. Lebih lanjut dalam hal ini pengenalan anak didik dalam hal gaya belajar menjadi unsur yang penting diperhatikan sebab faktor kematangan dan juga aspek kemampuan berpikir anak didik menjadi landasan berhasilnya strategi yang dilaksanakan.

Dalam konteks pendidikan Kristen, secara khusus Pendidikan Agama Kristen, maka upaya mengembangkan strategi

\footnotetext{
${ }^{32}$ Abdul Majid, 12.
} 
pembelajaran yang baik dan efektif harus didasarkan pada aspek keterlibatan kuasa Roh Kudus. Perhatikan Injil Matius 7:2829, Yesus mengajar dengan kuasa dan menjadikan hal itu sebagai pembeda cara mengajar Yesus dengan orang-orang Farisi dan ahli taurat. Pendidik Kristen harus dipenuhi Roh Kudus sehingga pola pengembangan strategi pembelajaran akan berdaya guna. Dengan mempertimbangkan faktor ilahi dan keterbukaan kepada dorongan kuasa Roh Kudus, guru dan murid akan mengalami pembaharuanpembaharuan dalam belajar dan mengajar. Hasil yang diharapkan ialah tercapainya perubahan mendasar dalam hal perilaku dan karakter, termasuk semakin kokohnya nilainilai kekristenan dalam diri peserta didik. Strategi pembelajaran transformatif mendorong setiap guru atau dosen bukan hanya mengajar berdasarkan sekumpulan prinsip dan filosofi mengajar, melainkan menghadirkan kuasa Roh Kudus dalam setiap interaksi belajar dan mengajar.

\section{DAFTAR PUSTAKA}

Ad. Rooijakkers, Mengajar Dengan Sukses: Petunjuk untuk Merencankan dan Menyampaikan Pengajaran, Jakarta: Grasindo dan YKPTK, 1993.

Aqib, Zainal, Profesionalisme Guru Dalam Pembelajaran, Surabaya: Insan Cendikia, 2002

Kemp , Jerold E. dkk, Designing Effective Instruction, Denver: John Wiley \& Son Inc, 2007

LeFerer, Marlen D, Creative Teaching Methods:Be An Effective Christian Teacher, Ilgin: David C.Cook Publishing Co, 1988

Majid, Abdul, Strategi Pembelajaran, Bandung: Rosda Karya, 2013.

Mukhtar \& Martinis Yamin, Metode Pembelajaran Yang Berhasil, Jakarta: Sasama Mitra Sukses, 2002

Ridwan Abudllah Sani, Inovasi Pembelajaran, Jakarta: Bumi Aksara, 2013
Masidjo, Ign, Penilaian Pencapaian Hasil Belajar Siswa Di Sekolah, Jogjakarta: Kanisius, 1995

Prawiradilaga, Dewi Salma, Prinsip Disain Pembelajaran, Jakarta: Kencana Prenada Media Group, 2007

Sanjaya, Wina, Perencanaan dan Desain Sistem Pembelajaran, Jakarta: Prenada Media Group, 2008

Sidjabat,B.S, Mengajar Secara Profesional, Bandung: Kalam Hidup, 2011

Soekartawi, Meningkatkan Efektivitas Mengajar, Jakarta: Dunia Pustaka Jaya, 1995.

Soekartawi, dkk., Meningkatkan Rancangan Instruksional (Instructonal Design) Untuk Memperbaiki Kualitas Mengajar, Jakarta: Raja Grafindo Persada, 1995

Zaini, Hisyam, Desain Pembelajaran di Perguruan Tinggi, Jawa Timur: CTSD, 2006

\section{BIODATA PENULIS}

Dr. Purim Marbun, M.Th., dilahirkan di Parbotihan, tanggal 29 September 1971. Menempuh pendidikan S1 di Institut Teologi dan Keguruan Indonesia (ITKI, Seminari Bethel/ sekarang STT Bethel Indonesia, Jakarta), S2 dari Universitas Kristen Indonesia (UKI), dan menyelesaikan S3, memperoleh gelar Doktor dari STT Bethel Indonesia. Penulis aktif dalam berbagai bidang pelayanan secara khusus di pendidikan. Menjadi dosen di Sekolah Tinggi Teologi Bethel Indonesia sampai saat ini; pernah menjabat sebagai: Pembantu Ketua I STT Bethel Indonesia periode 2012-2016; sebagai Ketua Departemen Pendidikan BPH-GBI periode 2014-2018. Saat ini Penulis menjabat sebagai Ketua STT Bethel Indonesia (periode 2016-2020). Selain itu, Penulis juga menjabat sebagai Bendahara pada PERSETIA (Perhimpunan Sekolah-sekolah Teologi di Indonesia) untuk periode 20182022. Penulis tinggal di Jakarta dan aktif melayani di berbagai tempat serta menggembalakan jemaat GBI Taman Anggrek. 
